\title{
Paracrine signalling loops in adult human and mouse pancreatic islets: netrins modulate beta cell apoptosis signalling via dependence receptors
}

\author{
Y. H. C. Yang • M. Szabat • C. Bragagnini • K. Kott • \\ C. D. Helgason • B. G. Hoffman • J. D. Johnson
}

Received: 19 October 2010 /Accepted: 8 November 2010 /Published online: 7 January 2011

(C) Springer-Verlag 2011

\begin{abstract}
Aims/hypothesis Adult pancreatic islets contain multiple cell types that produce and secrete well characterised hormones, including insulin, glucagon and somatostatin. Although it is increasingly apparent that islets release and respond to more secreted factors than previously thought, systematic analyses are lacking. We therefore sought to identify potential autocrine and/or paracrine islet growth factor loops, and to characterise the function of the netrin family of islet-secreted factors and their receptors, which have been previously unreported in adult islets.

Methods Gene expression databases, islet-specific tag sequencing libraries and microarray datasets of FACS purified beta cells were used to compile a list of secreted factors and receptors present in mouse or human islets. Netrins and their receptors were further assessed using RTPCR, Western blot analysis and immunofluorescence
\end{abstract}

Electronic supplementary material The online version of this article (doi:10.1007/s00125-010-2012-5) contains supplementary material, which is available to authorised users.

Y. H. C. Yang $\cdot$ M. Szabat $\cdot$ C. Bragagnini $\cdot$ K. Kott $\cdot$

J. D. Johnson $(\bowtie)$

Department of Cellular and Physiological Sciences,

University of British Columbia,

5358 Life Sciences Building, 2350 Health Sciences Mall,

Vancouver, BC, Canada V6T 1Z3

e-mail: jimjohn@interchange.ubc.ca

B. G. Hoffman

Department of Surgery, University of British Columbia,

Child \& Family Research Institute,

Vancouver, BC, Canada

C. D. Helgason

Department of Cancer Endocrinology,

BC Cancer Research Center,

Vancouver, BC, Canada staining. The roles of netrin- 1 and netrin- 4 in beta cell function, apoptosis and proliferation were also examined. Results We identified 233 secreted factors and 234 secreted factor receptors in islets. The presence of netrins and their receptors was further confirmed. Downregulation of caspase3 activation was observed when MIN6 cells were exposed to exogenous netrin- 1 and netrin-4 under hyperglycaemic conditions. Reduction in caspase-3 cleavage was linked to the decrease in dependence receptors, neogenin and unc-5 homologue $\mathrm{A}$, as well as the activation of Akt and extracellular signal-regulated protein kinase (ERK) signalling. Conclusions/interpretation Our results highlight the large number of potential islet growth factors and point to a context-dependent pro-survival role for netrins in adult beta cells. Since diabetes results from a deficiency in functional beta cell mass, these studies are important steps towards developing novel therapies to improve beta cell survival.

Keywords Axon guidance factors · Cytokines - Diabetes . Growth factors $\cdot$ Hormones $\cdot$ Netrin

$\begin{array}{ll}\text { Abbreviations } \\ \text { Akt } & \begin{array}{l}\text { v-Akt murine thymoma viral oncogene } \\ \text { homologue }\end{array} \\ \text { ASK1 } & \text { Apoptosis signal-regulating kinase 1 } \\ \text { DCC } & \text { Deleted in colon cancer } \\ \text { ERK } & \text { Extracellular signal-regulated protein kinase } \\ \text { FRET } & \text { Fluorescence resonance energy transfer } \\ \text { JNK } & \text { c-Jun N-terminal kinase 1 } \\ \text { UNC5 } & \text { Unc-5 homologue }\end{array}$

\section{Introduction}

Pancreatic islets are micro-organs that contain mainly insulin-secreting beta cells, as well as glucagon-secreting 
alpha cells and somatostatin-secreting delta cells. Rare cell types are also found, including multi-hormonal cells [1]. The loss of functional beta cell mass results in diabetes. Factors that could increase beta cell growth, survival or function are therefore urgently needed. In recent years, candidate gene studies have demonstrated that islets express and secrete factors in addition to the classical hormones, including multiple cytokines, neuropeptides and growth factors $[2,3]$. In parallel, targeted studies have revealed growth factors that promote islet cell survival when overexpressed or added exogenously. For example, we and others have demonstrated potent anti-apoptotic and proliferative roles of insulin and IGF-1 [4-6]. Increasing the production of islet glucagon-like peptide 1 is also protective [7]. A novel isoform of the anti-apoptotic hormone gastric inhibitory polypeptide is also produced in islets [8, 9]. Growth hormone, prolactin or placental lactogens can promote beta cell survival $[10,11]$. Similarly, overexpression of classical growth factors such as hepatocyte growth factor and fibroblast growth factor has been shown to exert positive effects on islets [12, 13], as has parathyroid hormone-related protein [14]. Activation of the erythroblastic leukaemia viral oncogene (ErbB) receptor pathway with betacellulin has been shown to protect beta cells and increase beta cell proliferation in a number of systems [15]. Emerging evidence suggests important roles for locally produced members of the TGF $\beta$ family, such as activin, follistatin and bone morphogenic proteins [16, 17]. These studies demonstrate that islet survival can be modulated by soluble factors, although in many cases it is not yet clear whether administration of these factors at doses that can be tolerated clinically will increase beta cell mass. Endogenous autocrine and/or paracrine signalling factors could be ideal starting points for diabetes therapies, as they can display local action and self-limiting feedback. Insulin is a potent, self-limiting islet survival factor [4] and a useful tool for in vitro preservation of functional islet mass, but the risk of hypoglycaemia makes insulin therapy for preventing loss of beta cell mass in vivo impractical. Other candidate local islet survival pathways have been investigated, including pituitary adenylyl cyclase-activating polypeptide [18], nerve growth factor [19] and Notch [20]. Nonetheless, our knowledge of the endogenous regulators of adult beta cell survival and proliferation remains insufficient. It is likely that many islet secreted factors and receptors remain undiscovered.

In the present study, we used gene expression databases to compile a list of 233 secreted factors and 234 receptors that are expressed in mouse or human islets, including those derived from FACS-purified human and mouse beta cells. Among these potential growth factors was a group of secreted molecules known to provide cellular and axonal guidance cues during neuronal development, comprising
Fig. 1 Identification of islet-secreted factors. Secreted factors expressed in human, mouse and/or rat islets were identified from ten independent sources and ranked according to expression level. Expression levels for T1DBase (relative expression), FACS-purified beta cells and purified islets microarray (relative expression), Massively parallel signature sequencing (MPSS; in transcripts per million [TPM]) and tag-sequencing library (Tag-Seq; in tags per million [tpm]) are displayed by colour (code as indicated; nd, data not determined). Figure shows 50 of the most highly expressed secreted factors. For a list of the remainder of 233 secreted factors, see ESM Table 3

members of the netrin, slit, semaphorin and ephrin protein families [21, 22]. Given the many parallels between development and cell fate decisions in neurons and the endocrine pancreas, we focused on the netrin family and their receptors. In multiple tissues, including the developing pancreas, netrins have been implicated as regulators of cell adhesion, migration, differentiation and organ morphogenesis $[21,23,24]$. They regulate apoptosis via their dependence receptors [25-27] and downstream signalling pathways involving v-akt murine thymoma viral oncogene homologue (Akt), extracellular signal-regulated protein kinase (ERK) and apoptosis signal-regulating kinase 1 (ASK1) $[21,25,26,28]$. Although it has been previously reported that netrin-1 expression is undetectable in adult pancreatic islet cells in the absence of tissue remodelling $[23,24]$, we show that multiple netrin proteins are present in adult beta cells, where they modulate caspase-3 activity in a context-dependent manner through the neogenin and unc-5 homologue (UNC5) A dependence receptors. Together, our genome-level findings point to a large number of potentially important local paracrine growth factor loops in pancreatic islets.

\section{Methods}

Bioinformatics and database search Secreted factors and receptors in mouse or human islet cells were identified through bioinformatic database search. Human islet genes were also confirmed in the Massively parallel signature sequencing (MPSS) data set of Kutlu et al. [29]. A mouse islet tag sequencing library was analysed for RefSeq accessions with tag counts greater than five as described $[30,31]$ (see also Electronic supplementary material [ESM] Methods). Briefly, DNaseI-treated total RNA isolated from hand-picked islets was used for tag sequencing libraries, sequenced to a depth of $7,481,000$ tags. Tags with a count of less than six were considered to be not expressed. In this way we identified 7,098 unique RefSeqs. A total of 4,810 RefSeq transcripts were expressed (ESM Table 1). The transcriptomes of human and mouse FACS-purified beta cells [32] were also analysed by microarray (for details, see 


\begin{tabular}{|c|c|c|c|c|c|c|c|c|c|c|c|c|}
\hline \multicolumn{13}{|l|}{ Colour code } \\
\hline Tag-Seq (tpm) & nd & 0 & 1 & 2 & 3 & 4 & 5 & 6 & 7 & 8 & 9 & $\geq 10$ \\
\hline $\begin{array}{l}\text { FACS purified cells and } \\
\text { purified islets } \\
\text { microarray (relative) }\end{array}$ & nd & 0 & $\begin{array}{l}1- \\
100\end{array}$ & $\begin{array}{r}101- \\
200\end{array}$ & $\begin{array}{r}201- \\
300\end{array}$ & $\begin{array}{r}301- \\
400\end{array}$ & $501-$ & $601-$ & $601-$ & $\begin{array}{l}701- \\
800\end{array}$ & $\begin{array}{r}801- \\
900\end{array}$ & $\geq 901$ \\
\hline $\begin{array}{l}\text { T1DBase (relative) } \\
\text { MPSS (TPM) }\end{array}$ & nd & 0 & $\begin{array}{l}1- \\
10\end{array}$ & $\begin{array}{c}11- \\
20\end{array}$ & $\begin{array}{r}21- \\
30\end{array}$ & $\begin{array}{c}31- \\
40\end{array}$ & $\begin{array}{c}41- \\
50\end{array}$ & $\begin{array}{l}51- \\
60\end{array}$ & $\begin{array}{l}61- \\
70\end{array}$ & $\begin{array}{c}71- \\
80\end{array}$ & $\begin{array}{c}81- \\
90\end{array}$ & $\geq 91$ \\
\hline
\end{tabular}

Gene symbol Gene name

INS (INS2) Insulin

SST

Somatostatin

MIF

Macrophage migration inhibitory factor

GCG

VEGFA

Glucagon

IAPP

Vascular endothelial growth factor A

SCG2

Islet amyloid polypeptide

CHGA

Secretogranin II (chromogranin C)

$P P Y$

Chromogranin A (parathyroid secretory protein 1)

SEMA4B

Pancreatic polypeptide

$R E G 1 B$

Sema domain, (semaphorin) 4B

SCG5

OLFM4

Regenerating islet-derived 1 beta

SCG3

Secretogranin V (7B2 protein)

Olfactomedin 4

CHGB

Secretogranin III

INS1

Chromogranin B (secretogranin 1)

GPI

$S A A 3$

GRN

IL8 Insulin I

Gucose phosphate isomerase, autocrine motility factor

Serum amyloid A3

HDGF

Granulin

$A D M$

Interleukin 8

SDF2L1

Hepatoma-derived growth factor

Adrenomedullin

IK

REG1A

Stromal cell-derived factor 2-like 1

EDN3

SDF2

SDF4

OLFM1

REGL

IL32

WNT4

NPY

NTN4

DLK1

CXCL16

TGFBI

CXCL2

GDF15

NELF

TFF3

FSTL1

PDGFA

NENF

IGF2

BMP5

JAG2

SEMA3E

WNT7B

IK cytokine, down-regulator of HLA II

Regenerating islet-derived 1 alpha

Endothelin 3

Stromal cell-derived factor 2

Stromal cell derived factor 4

Olfactomedin 1

Regenerating islet-derived-like

Interleukin 32

Wingless-type MMTV integration site family, member 4

Neuropeptide $Y$

Netrin 4

Delta-like 1 homologue (Drosophila)

Chemokine (C-X-C motif) ligand 16

Transforming growth factor, beta-induced, $68 \mathrm{kDa}$

Chemokine (C-X-C motif) ligand 2

Growth differentiation factor 15

Nasal embryonic LHRH factor

Trefoil factor 3 (intestinal)

Follistatin-like 1

Platelet-derived growth factor alpha polypeptide

Neuron derived neurotrophic factor

Insulin-like growth factor 2 (somatomedin A)

Bone morphogenetic protein 5

Jagged 2

Sema domain, (semaphorin) 3E

VEGFB

Wingless-type MMTV integration site family, member 7B

Vascular endothelial growth factor B
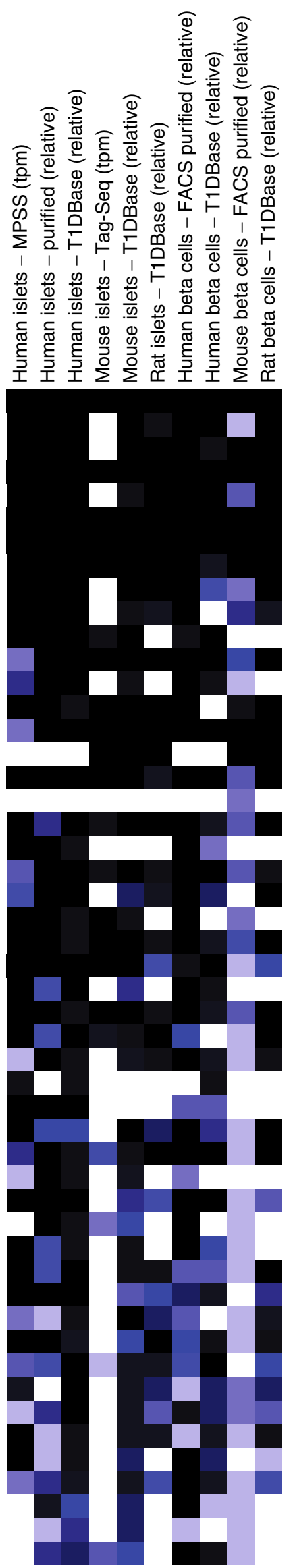
ESM Methods). Dispersed mouse or human islet cells were stably infected with reporter lentivirus for detection of $P d x 1$ and Ins 1 promoter activities. RNA was isolated from FACS-purified $\mathrm{PdxI}^{+} / \mathrm{Ins}^{+}$cells. cRNA was generated, labelled and hybridised to BeadChips (MouseWG-6 version 2.0, Human WG-6 version 3.0 BeadChips; Illumina, San Diego, CA, USA) for mouse or human samples, respectively. The Gene Expression Analysis Module in BeadStudio 3.3 software (Illumina) was used for background correction and normalisation. Probe sets with a detection $p$ value of $p<0.05$ were considered detected (i.e. significantly expressed). Gene expression was confirmed using T1Dbase [33]. Interactions between the ligands and receptors were found via PubMed.

Reagents Chemicals were from Sigma (St Louis, MO, USA) unless specified. Recombinant mouse netrin-1 and netrin-4 were from R\&D Systems (Minneapolis, MN, USA). Netrin1 rabbit monoclonal antibody was from Calbiochem (La Jolla, CA, USA). Polyclonal antibodies to netrin-4 (rabbit), neogenin (goat), UNC5A (goat) and UNC5C (goat) were from Santa Cruz (Santa Cruz, CA, USA). Guinea pig polyclonal insulin (Linco, St Charles, MO, USA), mouse monoclonal glucagon (Sigma), mouse monoclonal $\beta$-actin (Novus, Littleton, CO, USA) antibodies were purchased. Rabbit polyclonal antibodies to phospho-Akt (Ser473), phospho-Akt (Thr308), Akt, ERK1/2, phospho-ASK1 (Thr845), ASK1, phospho-c-Jun N-terminal kinase 1 (JNK) (Thr183/Tyr185) and JNK, and mouse monoclonal antibody phospho-ERK1/2 (Thr202/Tyr204) were from Cell Signaling Technology (Danvers, MA, USA). Draq5 nuclear stain was from Biostatus (Loughborough, UK).

Primary islet isolation and cell culture Pancreatic islets were isolated from 6- to 30-week-old male C57BL/6J mice (Jax, Bar Harbor, MA, USA) using collagenase and filtration. Mice were housed in accordance with the University of British Columbia Animal Care Committee guidelines. Human islets $(>80 \%$ purity estimated by dithizone staining) and pancreas were provided by G. Warnock (Department of Surgery, University of British Colombia), collected via protocols approved by the University of British Columbia Institutional Advisory Board. Donors were men and women aged 23 to 56 years. None of the donors were known to have diabetes. The islets were further hand-picked using a brightfield microscope. Islets were cultured overnight $\left(37^{\circ} \mathrm{C}, 5 \% \mathrm{CO}_{2}\right)$ in RPMI1640 medium (Invitrogen, Burlington, ON, Canada) with $5 \mathrm{mmol} / 1$ glucose (Sigma), $100 \mathrm{U} / \mathrm{ml}$ penicillin, $100 \mu \mathrm{g} / \mathrm{ml}$ streptomycin (Invitrogen) and $10 \%$ (vol./vol.) FBS (Invitrogen). MIN6 cells were cultured in Dulbecco's modified Eagle's medium (Invitrogen) containing $25 \mathrm{mmol} / 1$ glucose, $100 \mathrm{U} / \mathrm{ml}$ penicillin, $100 \mu \mathrm{g} / \mathrm{ml}$ streptomycin and 10\% (vol./vol.) FBS.
Fig. 2 Identification of islet secreted-factor receptors. Secreted factor receptors expressed in human, mouse and/or rat islets were identified from ten independent sources and ranked according to expression level. Expression levels for T1DBase (relative expression), FACSpurified beta cells and purified islets microarray (relative expression), Massively parallel signature sequencing (MPSS; in transcripts per million [TPM]) and tag-sequencing library (Taq-Seq; in tags per million [tpm]) are displayed by colour (code as indicated; nd, data not determined). Figure shows 50 of the most highly expressed secreted factor receptors. For a list of the remainder of 234 secreted factor receptors, see ESM Table 4

RT-PCR Total RNA was isolated from mouse primary islet and exocrine cells and MIN6 cells using Trizol, followed by clean-up with a kit (RNeasy; Qiagen, Mississauga, ON, Canada). Reverse transcription (SuperScript III; Invitrogen) was used to generate cDNA. PCR conditions and primer sequences are detailed in ESM Table 2. TaqMan quantitative RT-PCR was conducted using probes from Applied Biosystems (Streetsville, ON, Canada) and PerfeCTa qPCR SuperMix (Quanta, Gaithersburg, MD, USA) on a device (StepOnePlus; Applied Biosystems). Relative gene expression changes were analysed by $2^{-\Delta \mathrm{C}_{\mathrm{t}}}$ or $2^{-\Delta \Delta \mathrm{C}_{\mathrm{t}}}$ methods.

Immunofluorescence imaging and BrdU-labelling MIN6 cells were fixed in $4 \%$ (wt/vol.) paraformaldehyde (10 min) and permeabilised using $0.1 \%$ (vol./vol.) Triton $\mathrm{X}-100$ (10 min). Antigen retrieval was conducted on deparaffinised pancreas sections by boiling for $15 \mathrm{~min}$ in sodium citrate buffer $\left(10 \mathrm{mmol} / 1 \mathrm{Na}_{3} \mathrm{C}_{6} \mathrm{H}_{5} \mathrm{O}_{7}, 0.05 \%\right.$ (vol./ vol.) Tween-20, pH 6.0). Normal goat serum (10\% [vol./ vol.]) was used for blocking. Primary antibodies (1:50) were incubated overnight at $4^{\circ} \mathrm{C}$. Aminomethylcoumarin acetate (1:200; Jackson ImmunoResearch, West Grove, PA, USA) AlexaFluor-488- and -594-conjugated secondary antibodies (1:400; Invitrogen) were incubated for $1 \mathrm{~h}$ at $20^{\circ} \mathrm{C}$, prior to mounting in Vectashield (Vector Laboratories, Burlington, ON, Canada). Cells were imaged using an inverted microscope equipped with a 1.45 NA $\times 100$ objective. For proliferation analysis [5], MIN6 cells were seeded into 96-well plates and $10 \mu \mathrm{mol} / \mathrm{l}$ BrdU was supplemented to the medium following $2 \mathrm{~h}$ of treatment. Cells were stained with a BrdU labelling kit (Roche, Laval, QC, Canada) then imaged (ImageXpress Micro; Molecular Devices, Silicon Valley, CA, USA).

Immunoblotting MIN6 and islet cells were lysed with cell lysis buffer (Cell Signaling) containing protease inhibitors (Calbiochem). Lysates were sonicated for 20s then centrifuged for $10 \mathrm{~min}$ at $10,000 \mathrm{~g}$. Protein concentrations were determined using a bicinchoninic acid assay (Thermo, Rockford, IL, USA). Proteins were separated on $12 \%$ (wt/vol.) SDS-PAGE gels and transferred to polyvinylidene fluoride (PVDF) membranes. After blocking $(0.2 \%$ [wt/vol.] I-block, 0.1\% [vol./vol.] Tween-20 PBS), mem- 


\begin{tabular}{|c|c|c|c|c|c|c|c|c|c|c|c|c|}
\hline \multicolumn{13}{|l|}{ Colour code } \\
\hline Tag-Seq (tpm) & nd & 0 & 1 & 2 & 3 & 4 & 5 & 6 & 7 & 8 & 9 & $\geq 10$ \\
\hline $\begin{array}{l}\text { FACS purified cells and } \\
\text { purified islets } \\
\text { microarray (relative) }\end{array}$ & nd & 0 & $\begin{array}{c}1- \\
100\end{array}$ & $\begin{array}{l}101- \\
200\end{array}$ & $\begin{array}{r}201- \\
300\end{array}$ & $\begin{array}{r}301- \\
400\end{array}$ & $\begin{array}{c}401- \\
500\end{array}$ & $\begin{array}{l}501- \\
600\end{array}$ & $\begin{array}{l}601- \\
700\end{array}$ & $\begin{array}{l}701- \\
800\end{array}$ & $\begin{array}{l}801- \\
900\end{array}$ & $\geq 901$ \\
\hline $\begin{array}{l}\text { T1DBase (relative) } \\
\text { MPSS (TPM) }\end{array}$ & nd & 0 & $\begin{array}{l}1- \\
10\end{array}$ & $\begin{array}{c}11- \\
20\end{array}$ & $\begin{array}{r}21- \\
30\end{array}$ & $\begin{array}{c}31- \\
40\end{array}$ & $\begin{array}{c}41- \\
50\end{array}$ & $\begin{array}{c}51- \\
60\end{array}$ & $\begin{array}{c}61- \\
70\end{array}$ & $\begin{array}{c}71- \\
80\end{array}$ & $\begin{array}{c}81- \\
90\end{array}$ & $\geq 91$ \\
\hline
\end{tabular}

Gene symbol Gene name

ACVR1B Activin A receptor, type IB

IL10RB Interleukin 10 receptor, beta

ADIPOR2 Adiponectin receptor 2

TNFRSF10B Tumour necrosis factor receptor superfamily, member $10 \mathrm{~b}$

ADIPOR1 Adiponectin receptor 1

PLXNB2 Plexin B2

GPR177 G protein-coupled receptor 177

IGF2R Insulin-like growth factor 2 receptor

TNFRSF1A Tumor necrosis factor receptor superfamily, member $1 \mathrm{~A}$

IL1R1 Interleukin 1 receptor, type I

GPR172A G protein-coupled receptor 172A

NEO1 Neogenin homologue 1 (chicken)

GPR56 G protein-coupled receptor 56

ACVR1 Activin A receptor, type I

GPR108 G protein-coupled receptor 108

BMPR1A Bone morphogenetic protein receptor, type IA

$B A M B I \quad B M P$ and activin membrane-bound inhibitor homologue

IFNGR1 Interferon gamma receptor 1

IFNGR2 Interferon gamma receptor 2 (interferon gamma transducer 1)

LTBR Lymphotoxin beta receptor (TNFR superfamily, member 3)

TNFRSF12A Tumour necrosis factor receptor superfamily, member 12A

IL13RA1 Interleukin 13 receptor, alpha 1

AMFR Autocrine motility factor receptor

BMPR2 Bone morphogenetic protein receptor, type II

GPRC5C G protein-coupled receptor, family C, group 5, member C

SSTR2 Somatostatin receptor 2

IL17RB Interleukin 17 receptor B

LGR4 Leucine-rich repeat-containing G protein-coupled receptor 4

TNFRSF21 Tumour necrosis factor receptor superfamily, member 21

ACVR2A Activin A receptor, type IIA

GPR116 G protein-coupled receptor 116

UNC5CL Unc-5 homologue C (C. elegans)-like

FZD3 Frizzled homologue 3 (Drosophila)

PRLR Prolactin receptor

GPR180 G protein-coupled receptor 180

IGSF1 Immunoglobulin superfamily, member 1

GPR158 G protein-coupled receptor 158

NRXN1 Neurexin 1

PLXNA2 Plexin A2

NRP1 Neuropilin 1

KIAA1324L KIAA1324-like

PDGFRL Platelet-derived growth factor receptor-like

CSF2RA Colony stimulating factor 2 receptor, alpha, low-affinity

GPR137B G protein-coupled receptor 137B

$C R C P \quad$ Calcitonin gene-related peptide-receptor component protein

TGFBR2 Transforming growth factor, beta receptor II (70/80kDa)

NOTCH1 Notch homologue 1, translocation-associated (Drosophila)

OGFR Opioid growth factor receptor

TGFBR1 Transforming growth factor, beta receptor I

UNC5B Unc-5 homologue B (C. elegans)
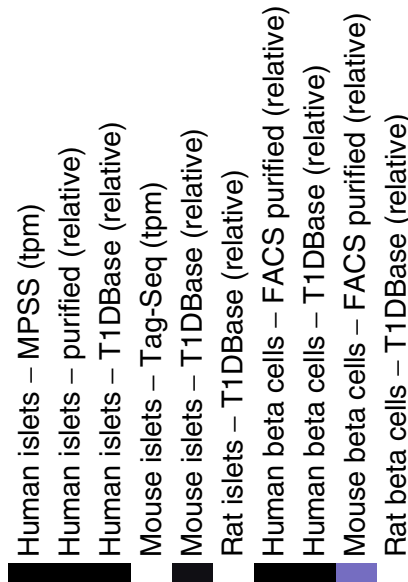

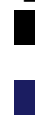

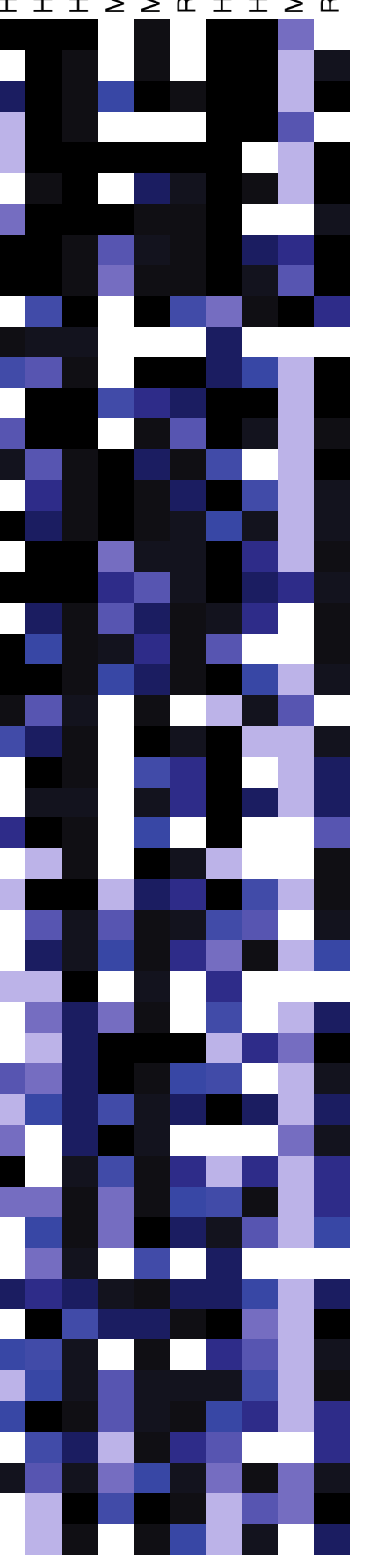


branes were probed with primary antibodies (1:1000), followed by horseradish peroxidase-conjugated secondary antibodies (1:3,000; Cell Signaling). Immunodetection was performed using enhanced chemiluminescence (Thermo).

Insulin and netrin secretion Mouse islets were perifused [20] and insulin secretion was measured by radioimmunoassay (Rat Insulin RIA Kit; Linco). Netrin-1 secretion was measured from 100 hand-picked human islets by ELISA (Enzo, Farmingdale, NY, USA).

cAMP and $\mathrm{Ca}^{2+}$ imaging MIN6 cells seeded onto glass coverslips were transfected with the AKAR2 fluorescence resonance energy transfer (FRET) probe [34] and imaged $48 \mathrm{~h}$ later. Cytosolic $\mathrm{Ca}^{2+}$ was imaged using Fura-2-AM (Invitrogen) as described [32]. Briefly, dispersed mouse islet cells seeded onto glass coverslips were loaded with $5 \mu \mathrm{mol} / \mathrm{l} \mathrm{Fura-2-AM}$ for $30 \mathrm{~min}$ at $37^{\circ} \mathrm{C}$. For cAMP and $\mathrm{Ca}^{2+}$ imaging, cells were incubated in Ringer's solution containing (in mmol/l): $5.5 \mathrm{KCl}, 2 \mathrm{CaCl}_{2}, 1 \mathrm{MgCl}_{2}, 20$ HEPES, $141 \mathrm{NaCl}$ and 3 glucose. Solutions were maintained at $37^{\circ} \mathrm{C}$ and cells were imaged using an inverted microscope (Zeiss $200 \mathrm{~m}$; Intelligent Imaging Innovations, Denver, CO, USA) operated by Slidebook 5.0 software (Intelligent Imaging Innovations).

Statistics Data are expressed as mean \pm SEM unless otherwise indicated. Results were considered statistically significant when $p<0.05$ using Student's $t$ test or ANOVA, where appropriate (GraphPad Prism; GraphPad, La Jolla, CA, USA).

\section{Results}

Bioinformatic and genomic analyses of islet secreted factors and receptors We used bioinformatics and genomics to search for secreted factors and their receptors employing up to ten independent lines of evidence for each gene. A list of 233 secreted factors and 234 receptors expressed in mouse or human islets was compiled from Serial analysis of gene expression (SAGE) and tag sequencing libraries, microarrays of FACS-purified human beta cells and online databases (Figs 1, 2, ESM Tables 3, 4). Secretable factors could be classified into four categories: axon guidance factors, growth factors, hormones and cytokines. As expected, insulin and somatostatin ranked as the two most abundantly expressed genes in islets. Glucagon and islet amyloid polypeptide occupied two of the other top six spots. Some of the other secreted factors that were highly expressed were unexpected. In particular, islets and beta cells have very high levels of macrophage migration inhibitory factor and vascular endothelial growth factor A mRNA. The analysis of
Fig. 3 Identification of islet-secreted factors and associated receptors. a Secreted factors and their associated receptors expressed in human, mouse and/or rat islets were identified from 10 independent sources, with expression levels displayed by colour as in Figs 1 and 2 (code as indicated; nd, data not determined). Known interactions between the factors and their receptors are represented by a connecting line. $\mathrm{CRH}$, corticotrophin releasing hormone; EGF, epidermal growth factor; FGF, fibroblast growth factor; TPM, transcripts per million; tpm, tags per million; VEGF, vascular endothelial growth factor; WNT, winglesstype MMTV integration site family. b Venn diagram representing the 233 ligands and the 234 receptors found, as well as the 190 potential known interactions between 95 ligands (Lig) and 89 receptors (Rec)

receptors across multiple databases was also highly informative. The type 1B activin A receptor was the most highly expressed receptor gene and many of the highest expressed genes were members of the TGF pathway. Receptors for adiponectin occupied two spots in the top five ranked genes. Commonly studied receptors, such as those for insulin, glucagon and glucagon-like peptide 1 were abundant (i.e. found in the top third of expressed receptor genes; Fig. 2, ESM Table 4), but not in the top ten.

In total, 190 autocrine and/or paracrine signalling pairs, consisting of both the secreted factor and its known receptor, were identified in islets (Fig. 3a). We and others have investigated the roles of TGF $\beta$ family members in islet function, including the reciprocal effects of local activin and follistatin on beta cell maturation [16]. We have also examined notch signalling [20]. The wingless-type MMTV integration site family (WNT)/frizzled (FZD) system has been under intense study since the implication of transcription factor 7-like 2 (TFC7L2) in type 2 diabetes. Follow-up of each gene family was beyond the scope of the present study.

Netrins are expressed in adult mouse and human islets Among the more interesting families of ligand/receptor pairs were netrins and their receptors, best known for their roles in providing axonal guidance cues during neuronal development [21]. Actions of netrins outside of neuronal development have been described in mammary gland and lung branching morphogenesis [21, 24, 35, 36]. Netrins have been ascribed a role in pancreatic development [21, $23,24]$, but were previously undetected in adult islet cells in the absence of injury [23, 24]. Three secreted netrins (netrin-1, -3, -4) and the two glucose-6-phosphate isomerase-anchored sub-classes (netrin-G1, netrin-G2) were identified via bioinformatics and genomics in mouse and human islets (Fig. 1, ESM Table 3). Netrin-4 and netrin-1 were identified as the 34th and 129th most abundant isletsecreted factors (Fig. 1, ESM Table 3), so we decided to focus on them, rather than on the less abundant netrin-3 and the glucose-6-phosphate isomerase-anchored isoforms. RTPCR confirmed mRNA expression of the major netrin secreted factors in MIN6 cells and primary adult mouse 

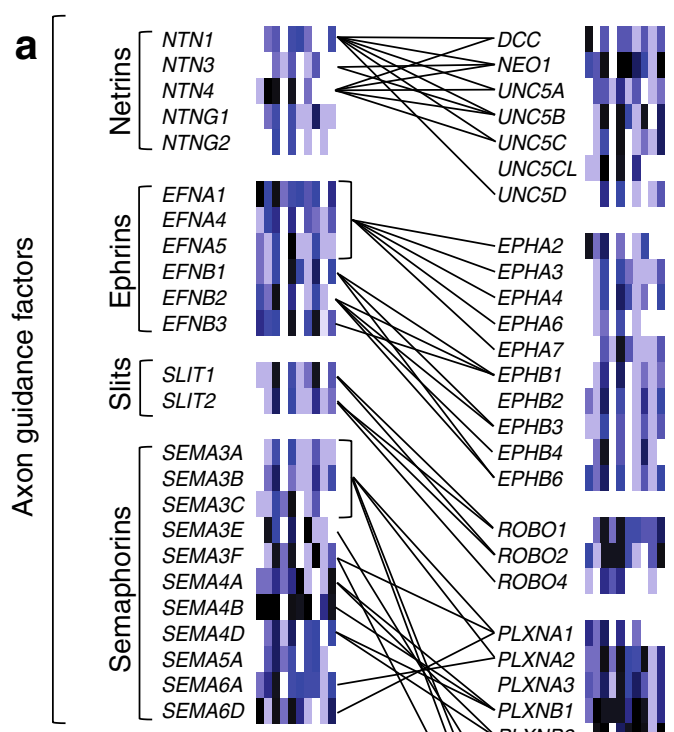

(2) EFNA

EFNA5

나 $E F N B 2$

LEFNB3

$\stackrel{\oplus}{\leftrightarrows}\left[\begin{array}{l}\text { SLIT1 } \\ \text { SLIT2 }\end{array}\right.$

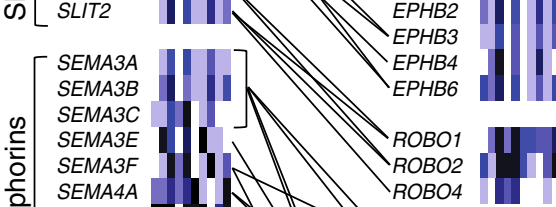

은 SEMA4A

SEMA4B

Ф) SEMA5A SEMA6A SEMA6D

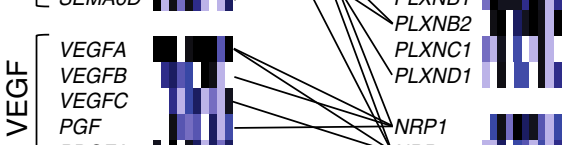

Ð $P G F$

PDGFA

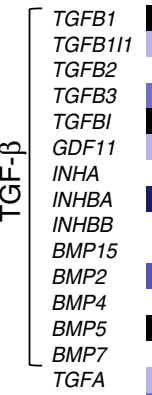

BMP1

Ш্口ে $\left[\begin{array}{l}B T C \\ E G F \\ N R G\end{array}\right.$

NRG
NMB

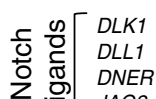

닌 $\left[\begin{array}{l}\text { FGF1 } \\ \text { FGF11 } \\ \text { FGF12 } \\ \text { FGF13 } \\ \text { FGF14 } \\ \text { FGF2 } \\ \text { FGF7 } \\ \text { FGF9 }\end{array}\right.$

HGF

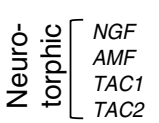

Ł $\left[\begin{array}{l}\text { WNT1 } \\ \text { WNT11 } \\ \text { WNT2 } \\ \text { WNT2B } \\ \text { WNT3 } \\ \text { WNT4 } \\ \text { WNT5A } \\ \text { WNT5B } \\ \text { WNT7A } \\ \text { WNT8A }\end{array}\right.$

FRZB
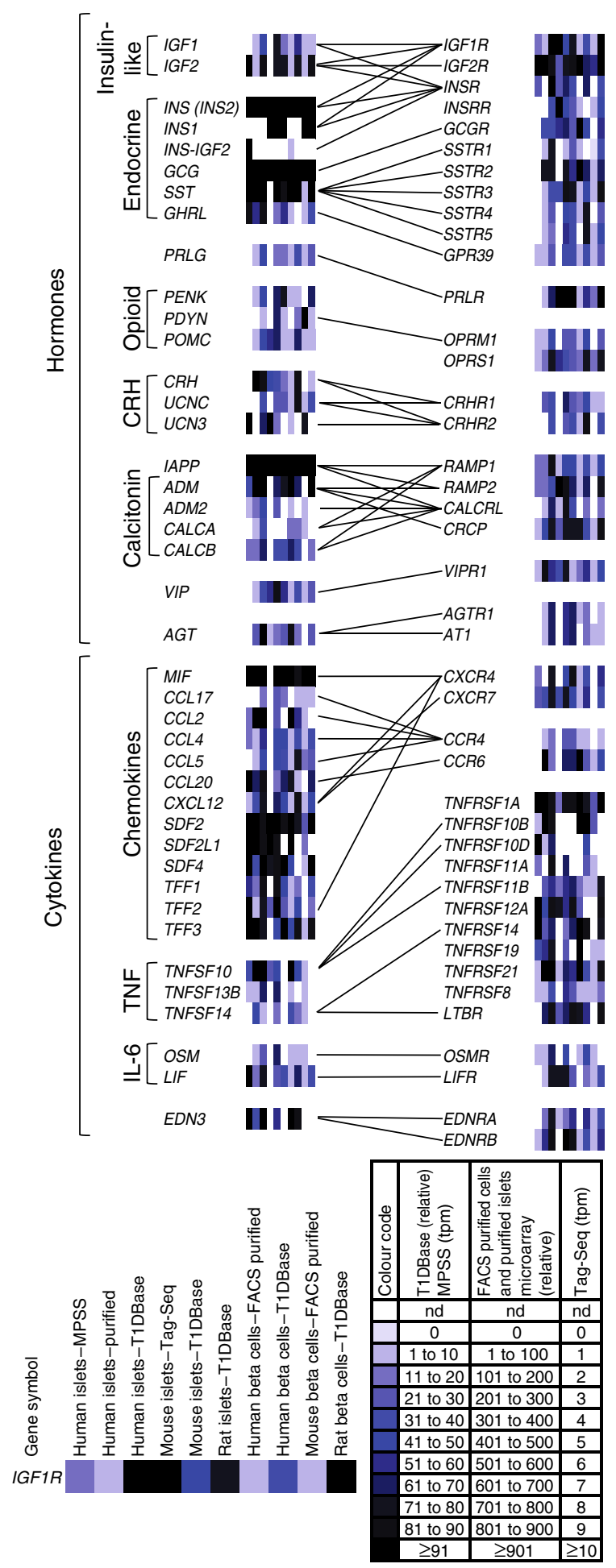

b

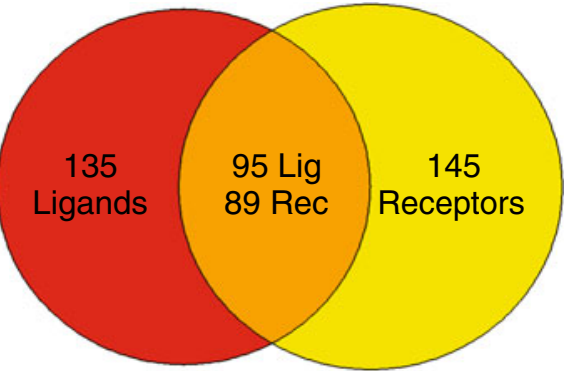


islets isolated from 6- to 24-week-old mice (Fig. 4a). However, in MIN6 cells, netrin-4 transcript was not detected. Quantitative RT-PCR of FACS-purified human beta cells further confirmed the expression of netrin-1 and netrin-4 (Fig. 4b). Netrin-1 and netrin-4 protein was confirmed by immunoblotting of human and mouse islets (Fig. 4c, d). Netrin was more prominent in mouse islets than in exocrine tissue. Netrin- 1 and netrin- 4 antibodies showed two bands in human islets, possibly representing the known netrin variants [37]. Netrin-1 and netrin-4 levels were most prominent in islets from older mice, which is perhaps why we did not see robust protein production in the sub-differentiated MIN6 cells. Netrin-1 immunoreactivity was detected in mouse and human beta cells, but not in alpha cells (Fig. 4e, f). Netrin-4 immunoreactivity was detected in mouse beta and alpha cells, but only in beta cells in human tissue (Fig. 4e, f). Together with the bioinformatics described above, these data demonstrate unequivocally that netrins are present in adult pancreatic beta cells. Netrins signal through the extracellular domain of their receptors and must be secreted to be functional. Netrin-1 was constitutively secreted from human islets, independently of high glucose or arginine (Fig. 4g). Indeed, insulin and netrin-1 were stored in distinct secretory granules (Fig. 4h). Efforts to measure netrin-4 by ELISA were unsuccessful; however, we did observe distinct insulin and netrin-4 secretory granules (Fig. 4i).

Netrin signalling regulates caspase-3 activity, but not insulin release or proliferation The expression of netrins in adult beta cells begs the question of their functional role. Netrin-1 and netrin-4 each decreased caspase-3 cleavage under hyperglycaemic conditions, suggesting a role in apoptosis (Fig. 5a, c). A trend towards decreased cleaved caspase-3 was also observed when mouse islets were treated with netrin-1 and $25 \mathrm{mmol} / 1$ glucose (ESM Fig. 1). Interestingly, under $5 \mathrm{mmol} / 1$ glucose conditions, netrin-1 increased cleaved caspase-3 following $16 \mathrm{~h}$ of treatment (Fig. 5a), but not after short treatments (ESM Fig. 2a, b), suggesting a temporal effect of netrin-1. While netrins promote proliferation in some cell types [28, 38, 39], neither netrin-1 nor netrin-4 had significant effects on BrdU incorporation in MIN6 beta cells (Fig. 5b, d). Exogenous netrin-1 and netrin- 4 did not have significant effects on glucose-stimulated insulin secretion from mature mouse beta cells (Fig. 5e).

Neogenin and UNC5A mediate the effects of netrin-1 and netrin-4 The axonal guidance by netrins is mediated through DCC and UNC5 dependence receptors [21]. In adult mouse islets, mRNA for Unc5a,Unc5b,Unc5c and neogenin, but not Unc5d or Deleted in colon cancer $(D c c)$, was detected by RT-PCR (Fig. 6a). Western blots confirmed
Fig. 4 Expression of netrins in adult mouse and human islet and exocrine cells. a Expression of netrins was assessed by RT-PCR of RNA isolated from MIN6 cells (passages 27, 38, 46), as well as islets from mice of different ages $(n=3)$. Positive and negative controls were RT-PCR of RNA from mouse brain, with and without reverse transcriptase. b Quantitative RT-PCR of RNA isolated from FACSpurified human beta cells: relative differences in gene expression compared with $\beta$-actin were analysed by $2^{-\Delta C_{t}}$ method. c Western blotting of protein lysates from MIN6 cells (passages 18, 43, 46) and from 6-, 12- and 30-week-old mouse islet and exocrine cells. Positive control was lysate from mouse brain. d Western blotting of protein lysates isolated from mouse (M) and human $(\mathrm{H})$ islet cells. e Immunofluorescence staining for netrin-1 (NTN1) and netrin-4 (NTN4) in mouse pancreas sections, co-stained with antibodies to insulin (INS) and glucagon (GCG). Nuclei were stained with Draq5. Scale bar, $10 \mu \mathrm{m}$. f Immunofluorescence staining as above (e) in human pancreas sections. Scale bar, $10 \mu \mathrm{m}$. g Netrin-1 release from human islets perifused in $3 \mathrm{mmol} / \mathrm{l}$ and $15 \mathrm{mmol} / 1$ glucose $\mathrm{KRB}$, and $15 \mathrm{mmol} / \mathrm{l}$ arginine (Arg, $n=5$ ). Immunofluorescence staining for netrin-1 (h) and netrin-4 (i), both with insulin in human beta cells. Scale bars are $10 \mu \mathrm{m}$ for whole beta cell images, $1 \mu \mathrm{m}$ for adjacent zoomed-in images

the presence of UNC5A, UNC5C and neogenin proteins in mouse islets, where age-dependent differential expression patterns were observed (Fig. 6a, b). Neogenin, UNC5A and UNC5C immunoreactivity was found in mouse and human alpha cells and beta cells (Fig. 6c, d).

Neogenin and UNC5 dependence receptors induce apoptosis in the absence of netrin ligand and inhibit apoptosis when netrin is bound [40, 41]. Netrin downregulates these receptors in other cell types [42]. Indeed, exogenous netrin-1 significantly decreased neogenin and UNC5A protein levels in beta cells (Fig. 7a, b). Transfection of MIN6 cells with netrin-1 also decreased neogenin levels, suggesting constitutive autocrine signalling (Fig. $7 \mathrm{~g}$ ). Netrin-1 also decreased neogenin, but not UNC5A, in mouse islets (Fig. 7e, f). When MIN6 cells were treated with exogenous netrin- 4 under high glucose, a decrease in UNC5A levels was observed, while neogenin remained unchanged (Fig. 7c, d). Together these data suggest that netrin- 1 and netrin- 4 decrease caspase-3 cleavage in adult beta cells via downregulation of distinct dependence receptors, specifically under high glucose conditions. Interestingly, glucose alone caused a significant increase in UNC5A protein levels (Fig. 7b, d).

To determine whether the observed decrease in neogenin and UNC5A levels following netrin treatment was due to changes in gene transcription or protein degradation, we conducted quantitative RT-PCR on RNA from netrin-treated MIN6 cells. Netrin-1 or netrin-4 treatment, in 5 or $25 \mathrm{mmol} / 1$ glucose, did not affect neogenin or Unc5a mRNA (Fig. 7h, i), suggesting that netrins modulate receptor protein levels via degradation. This was consistent with the rapid decrease in neogenin protein upon netrin-1 treatment (ESM Fig. 3a, b).

Netrin treatment acutely induces Akt and ERK pro-survival signalling The mechanism by which netrin reduces 

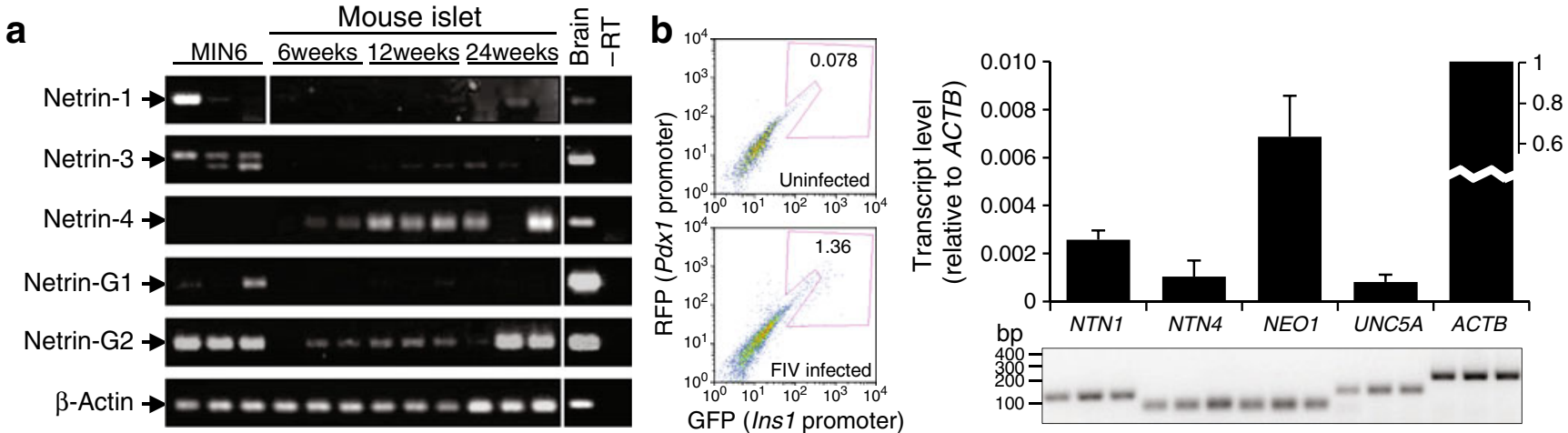

C
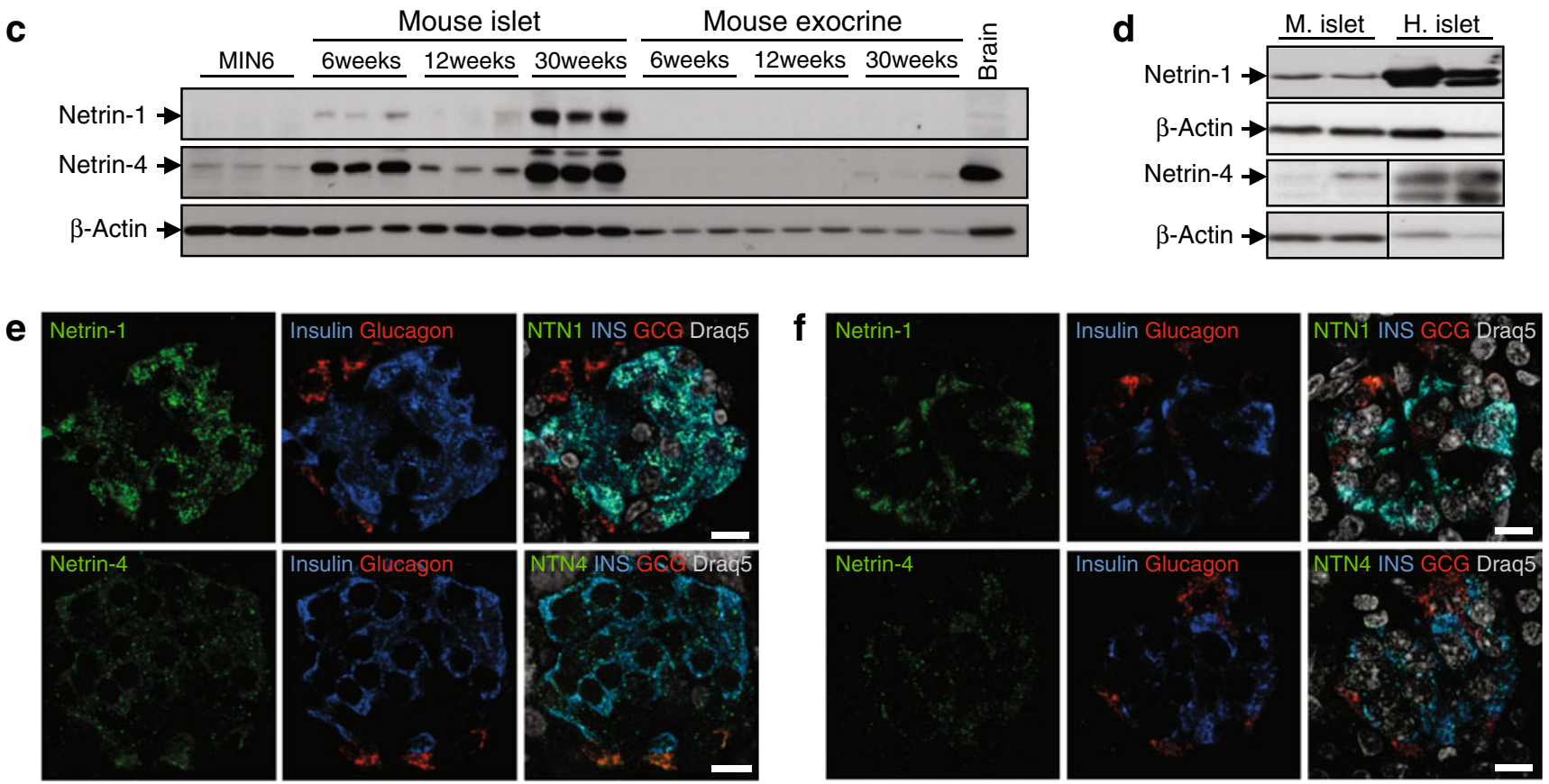

g

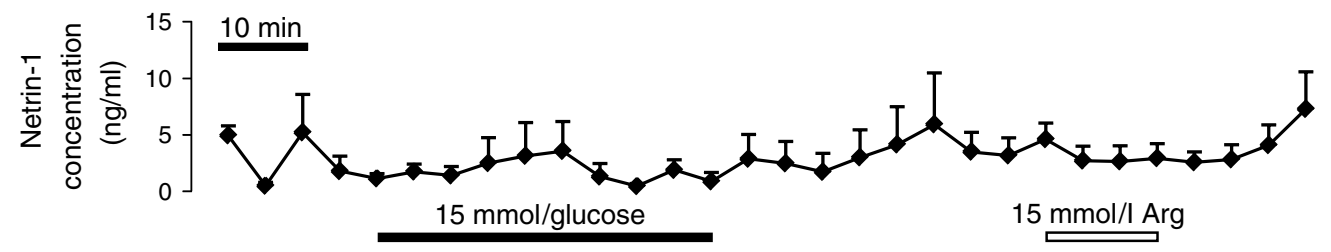

h
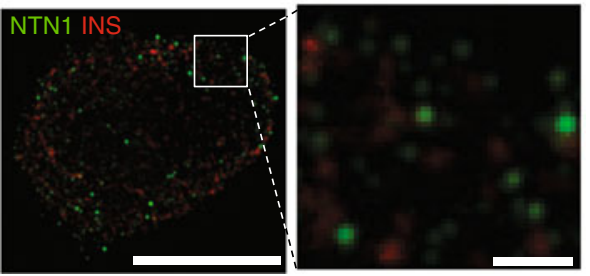
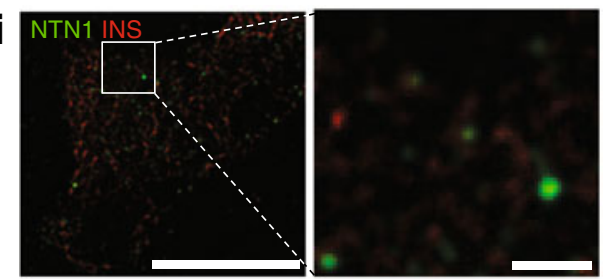

caspase-3 activation was further investigated by immunoblot. Akt and ERK were phosphorylated after $5 \mathrm{~min}$ of $15 \mathrm{nmol} / \mathrm{l}$ netrin-1 or netrin-4 in $25 \mathrm{mmol} / \mathrm{l}$, but not in $5 \mathrm{mmol} / \mathrm{l}$ glucose (Fig. $8 \mathrm{a}-\mathrm{c})$. Netrin-1 $(0.15 \mathrm{nmol} / \mathrm{l})$ activated the Akt and ERK pathways under $5 \mathrm{mmol} / \mathrm{l}$ glucose. Following $60 \mathrm{~min}$ treatment with $15 \mathrm{nmol} / \mathrm{l}$ netrins, Akt phosphorylation remained significant and the stimulation of ERK phosphorylation was abolished (ESM Fig. 4a-c). 
a

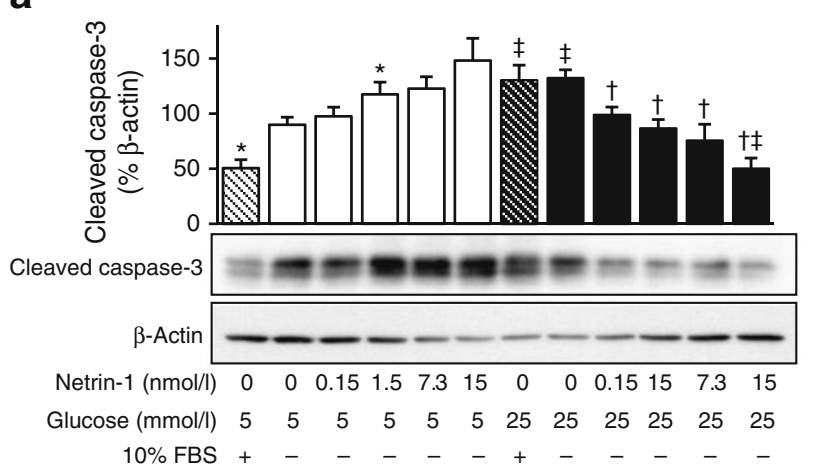

C

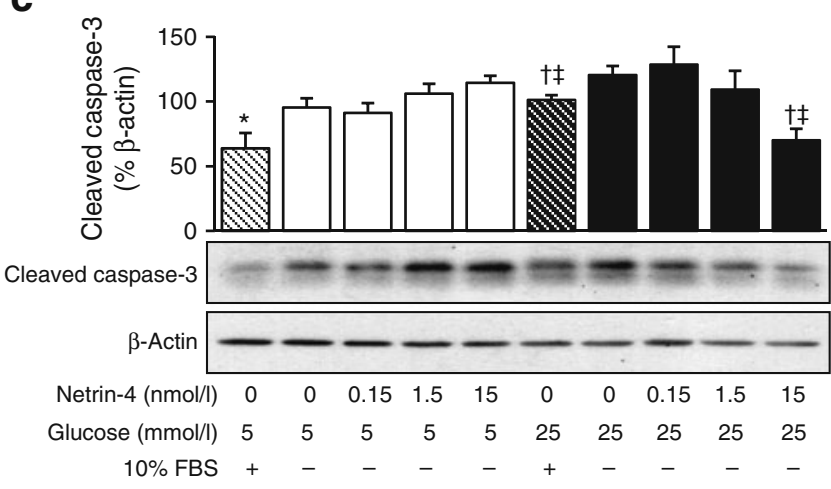

b

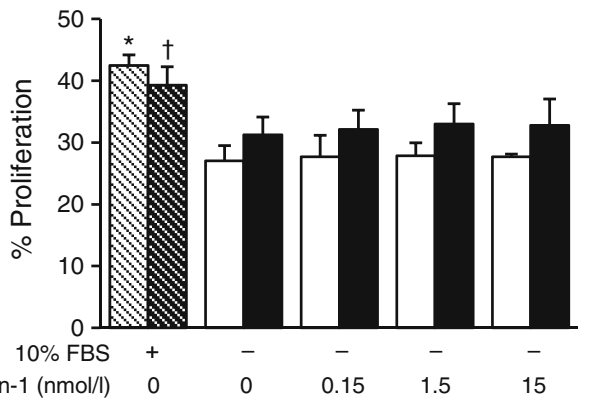

d

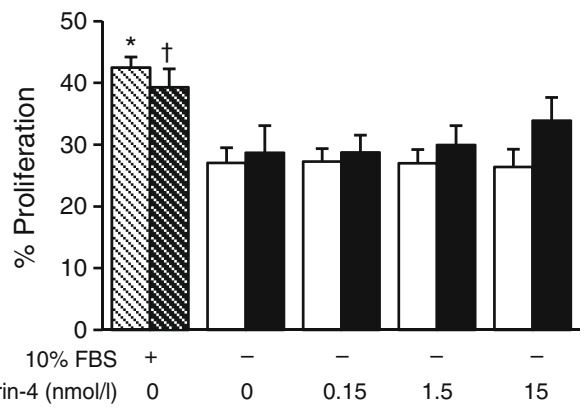

e

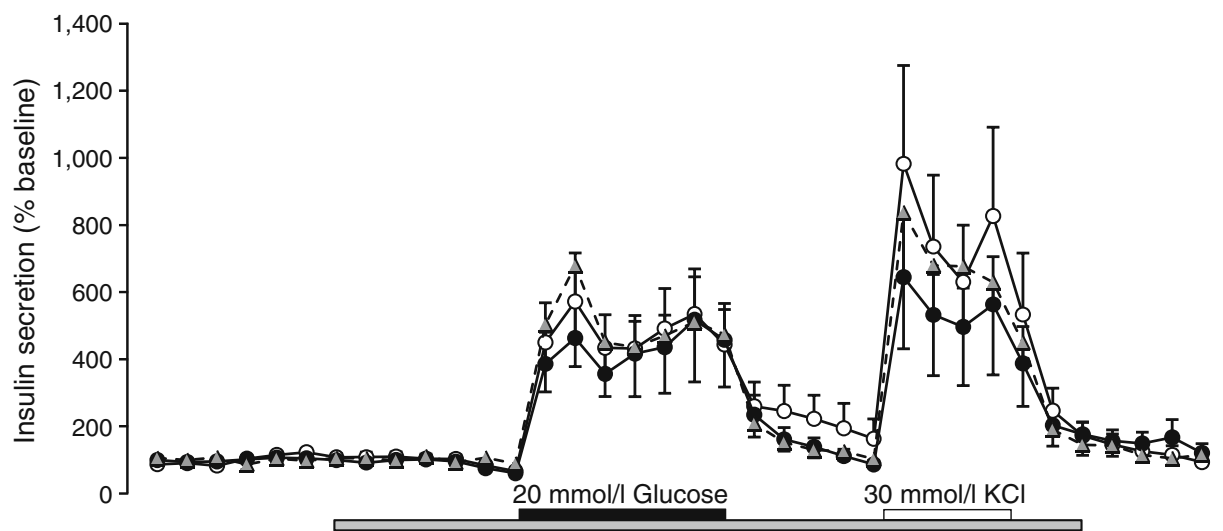

Fig. 5 Effects of netrin-1 and netrin-4 on MIN6 cell viability, proliferation and insulin secretion. a Cleaved caspase-3 in MIN6 cells treated with netrin-1 and (c) netrin- 4 under $5 \mathrm{mmol} / \mathrm{l}$ (white bars) or $25 \mathrm{mmol} / 1$ (black bars) glucose for $16 \mathrm{~h}$ was detected by Western blotting and quantified by densitometry as percentage of $\beta$-actin $(n=7)$. b Proliferation of MIN6 cells treated for $6 \mathrm{~h}$ with various doses of recombinant mouse netrin-1 or (d) netrin-4 under serum-free conditions. Serum-containing medium was used as a positive control

Netrin treatment did not change the phosphorylation level of JNK1 (Fig. 8d, ESM Fig. 4d). However, under low glucose conditions netrin-4 treatment significantly upregulated ASK1-Thr845 phosphorylation, suggesting ASK1dependent apoptosis (Fig. 8e).

Netrin-1 does not induce acute cAMP or $\mathrm{Ca}^{2+}$ signals Netrin-1 has previously been found to induce cAMP- and
( $n=4 ; 5 \mathrm{mmol} / 1$ glucose control, hatched white bars; $25 \mathrm{mmol} / 1$ glucose control, hatched black bars). ${ }^{*} p<0.05$ compared with $5 \mathrm{mmol} / \mathrm{l}$ glucose control; ${ }^{\dagger} p<0.05$ compared with $25 \mathrm{mmol} / 1$ glucose control; ${ }^{\star} p<0.05$ compared with $5 \mathrm{mmol} / \mathrm{l}$ glucose of the same treatment. e Glucoseand $\mathrm{KCl}$-stimulated insulin secretion from mouse islets perifused with $1.5 \mathrm{nmol} / 1$ netrin-1 (black circles) or netrin-4 (grey triangles); white circles, untreated. $n=6$

ryanodine receptor-dependent $\mathrm{Ca}^{2+}$ signals in neurons [43]. To determine whether cAMP is important for netrin-1 signalling in beta cells, we conducted live cell imaging with a FRET-based cAMP probe (AKAR2). First, we validated AKAR2 function in MIN6 cells. Indeed, AKAR2 was diffusely cytoplasmic and exhibited rapid FRET changes upon perifusion with the cAMP-activating hormone glucagon-like peptide 1 or the adenylate cyclase-activating drug forskolin 

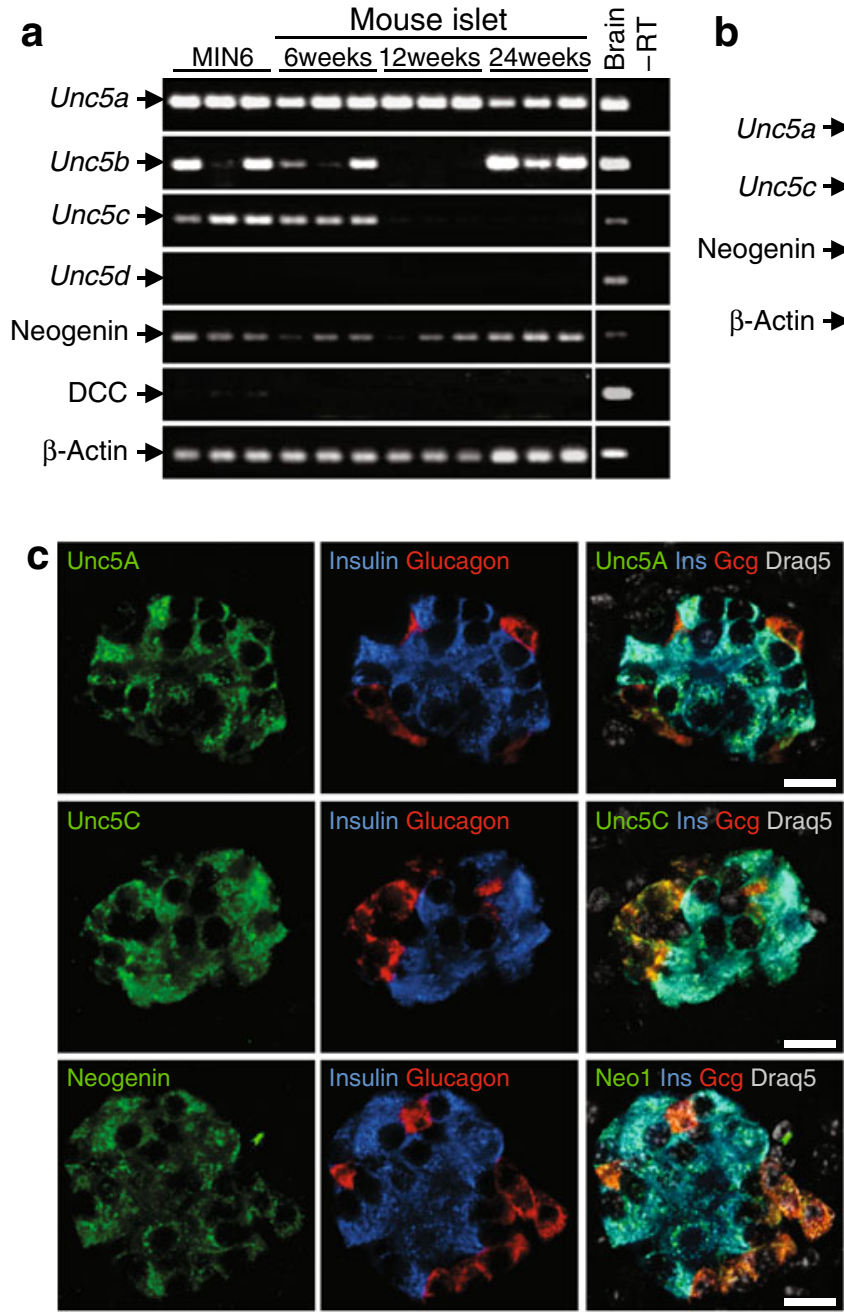

Fig. 6 Neogenin, UNC5A and UNC5C in adult mouse islet cells. a Expression of neogenin, Unc5a, Unc5b and Unc5c was detected by RT-PCR of RNA isolated from MIN6 cells and from 6-, 12- and 24week-old mouse islet cells $(n=3)$. Positive and negative controls were RT-PCR of RNA from mouse brain, with and without reverse transcriptase. b Netrin detected by Western blotting of lysates isolated

(ESM Fig. 5a, b). Treatment with $15 \mathrm{nmol} / 1$ netrin-1 for $30 \mathrm{~min}$ in a static bath resulted in only miniscule, delayed FRET signals (ESM Fig. 5c). Thus, rapid cAMP signalling may not be critical for acute netrin signalling in beta cells. We also examined intracellular $\mathrm{Ca}^{2+}$ using Fura-2 and found that netrin-1 had no effect in islet cells (ESM Fig. 5d) and MIN6 cells. Therefore, netrin-1 does not mediate its acute effects on beta cells through the same pathways that it employs to control axon growth cone turning.

\section{Discussion}

The identification of factors that protect islets and increase functional beta cell mass is a major research goal. Here, we
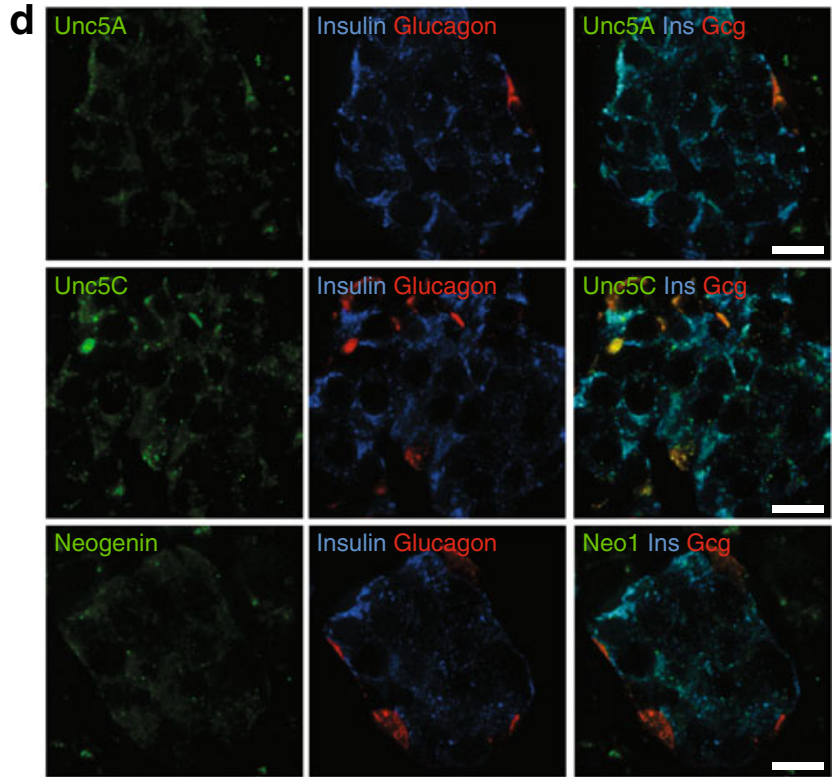

from MIN6 cells and from 6-, 12- and 30-week-old mouse islet and exocrine cells. Positive control was lysate from mouse brain. c Immunofluorescence staining of mouse and (d) human pancreas sections was used to detect the presence of neogenin, UNC5A and UNC5C in islets co-stained with antibodies to insulin (Ins) and glucagon $(\mathrm{Gcg})$. Nucleus was stained with Draq5. Scale bar, $10 \mu \mathrm{m}$

employed an unbiased approach to catalogue 233 secreted factors and 234 receptors found in islets, many of them previously unappreciated. Our results also confirmed that several previously investigated candidate islet survival factors, such as hepatocyte growth factor and its receptor c-met [13, 44, 45] are found in islets. Urocortin 3 and nerve growth factor, along with their receptors, are other examples of autocrine islet survival factors $[19,46]$. The identification of axonal guidance factors in islets, including netrins, was a surprising finding of our unbiased analysis. In addition to neuronal development, netrins have been implicated in mammary, lung and pancreas development $[21,24,35,36]$. In the developing pancreas, netrins act as regulators of cell adhesion, migration and differentiation $[21,23,24]$. Netrins were thought to be absent in adult 
a

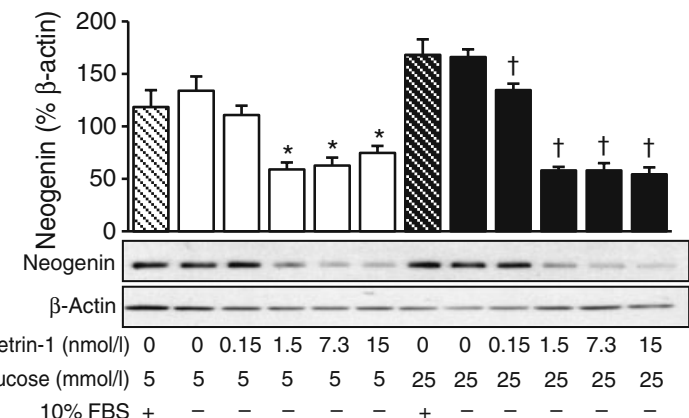

C

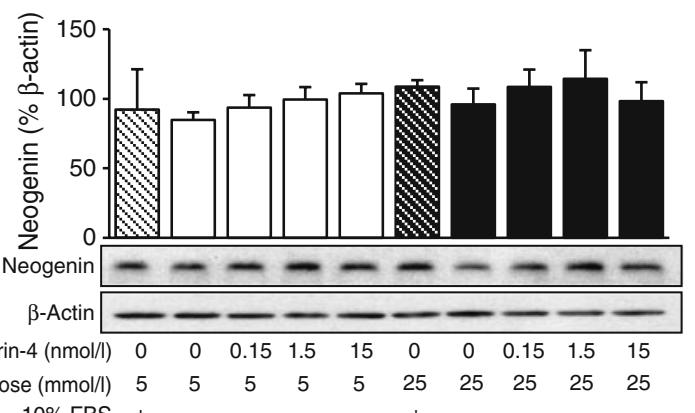

b

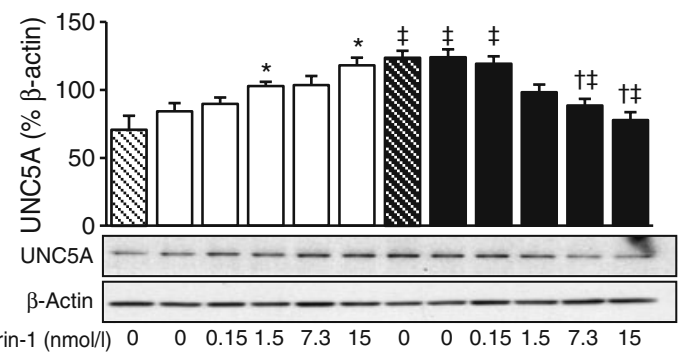

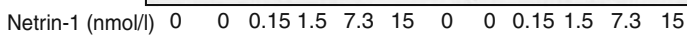

$\begin{array}{lllllllllllll}\text { Glucose }(\mathrm{mmol} / \mathrm{l}) & 5 & 5 & 5 & 5 & 5 & 5 & 25 & 25 & 25 & 25 & 25 & 25\end{array}$

$10 \%$ FBS +

d

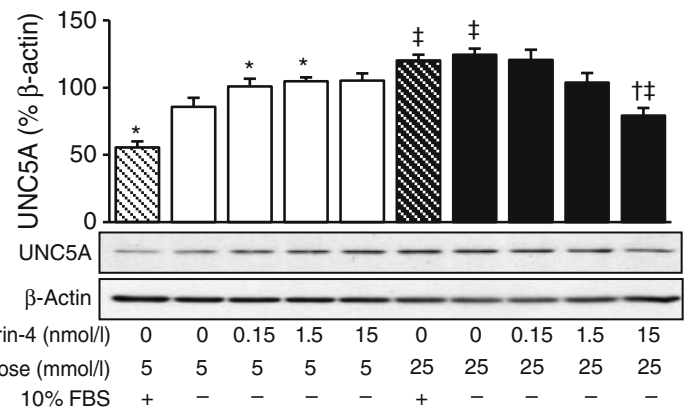

e

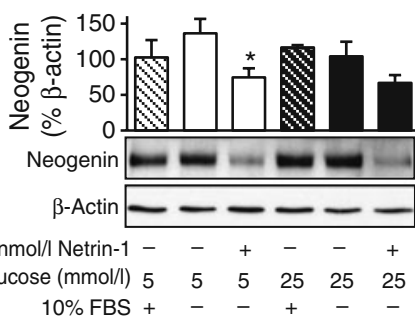

h

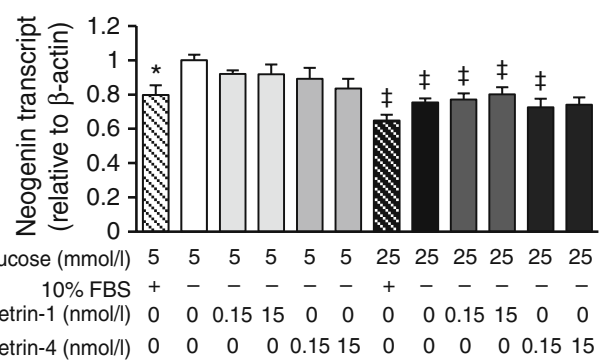

Fig. 7 Effects of netrins on levels of associated receptors. The protein levels of neogenin and UNC5A, normalised to $\beta$-actin, were detected by Western blotting in MIN6 cells treated for $16 \mathrm{~h}$ with 0 to $15 \mathrm{nmol} / 1$ netrin-1 (a, b) or netrin-4 (c, d) in DMEM medium supplemented with $5 \mathrm{mmol} / 1$ (white bars) or $25 \mathrm{mmol} / 1$ (black bars) glucose $(n=6-7)$. e Protein levels of neogenin and UNC5A (f), normalised to $\beta$-actin, were detected by Western blotting in mouse islets treated for $72 \mathrm{~h}$ with RPMI medium supplemented with $15 \mathrm{nmol} / 1$ netrin-1 $(n=3)$. g The

pancreatic islets $[23,24]$. Our results show that all netrin genes are expressed in adult mouse islets. Netrin receptors (neogenin, UNC5A, UNC5B and UNC5C) were also found in adult mouse and human islets. Consistent with previous reports, DCC was not found in adult islets [23]. There appeared to be age-dependent changes in levels of netrins g

$\begin{array}{lllllll}\text { Glucose (mmol/l) } & 5 & 5 & 5 & 25 & 25 & 25\end{array}$

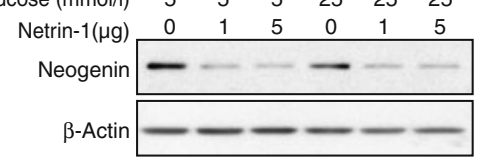

$-\quad+\quad+\quad-25$

i

protein level of neogenin was detected by Western blotting in MIN6 cells $48 \mathrm{~h}$ after transfection with a netrin-1 construct. The expression of neogenin (h) and Unc5a (i) were detected by quantitative RT-PCR in MIN6 cells treated with netrin-1 or netrin-4 for $16 \mathrm{~h}(n=3)$. Relative changes in gene expression were analysed by $2^{-\Delta \Delta \mathrm{Ct}}$ method. ${ }^{*} p<0.05$ compared with $5 \mathrm{mmol} / \mathrm{l}$ glucose serum-free control; ${ }^{\dagger} p<0.05$ compared with $25 \mathrm{mmol} / \mathrm{l}$ glucose serum-free control; ${ }^{\star} p<0.05$ compared with $5 \mathrm{mmol} / \mathrm{l}$ glucose of the same treatment

and their receptors. Islet expression of netrins and their receptors suggest that local autocrine or paracrine netrin signalling exists in adult islets. Additionally, the downregulation in neogenin protein as a result of netrin-1 overexpression further suggests existence of an autocrine signalling mechanism. 
a
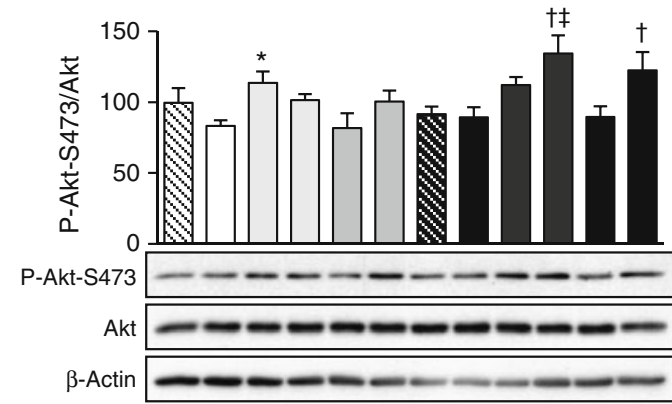

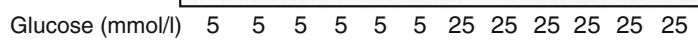

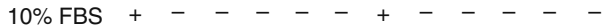

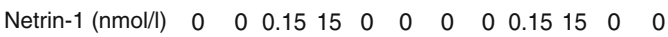

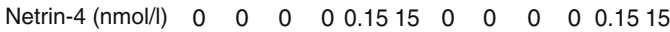

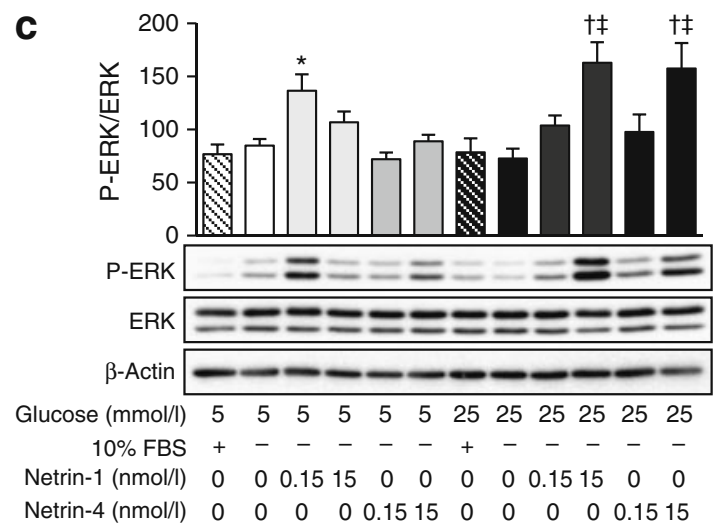

b

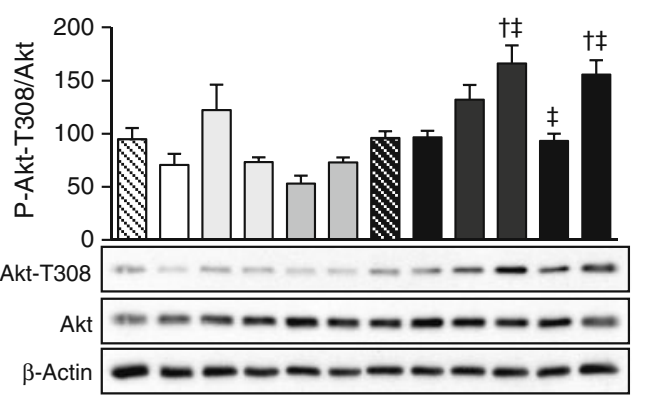

$\begin{array}{lllllllllllll}\text { Glucose }(\mathrm{mmol} / \mathrm{l}) & 5 & 5 & 5 & 5 & 5 & 5 & 25 & 25 & 25 & 25 & 25 & 25\end{array}$

$10 \%$ FBS + - - - - + - - -

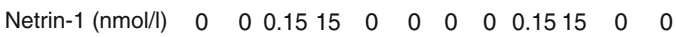

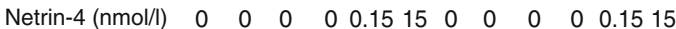

d

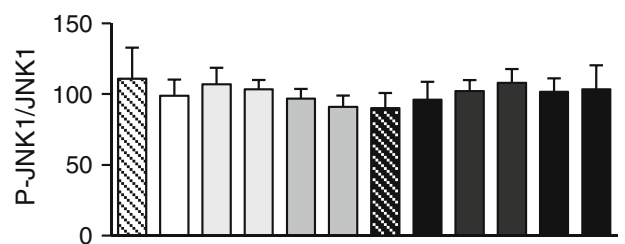

P-JNK1 $=m-\infty-\infty-\infty-\infty$

JNK1 $-m-\infty-\infty-\infty-\infty$

$\beta$-Actin

$\begin{array}{lllllllllllll}\text { Glucose }(\mathrm{mmol} / \mathrm{l}) & 5 & 5 & 5 & 5 & 5 & 5 & 25 & 25 & 25 & 25 & 25 & 25\end{array}$

$10 \% \mathrm{FBS}+---\quad-+-\quad-\quad-\quad-$

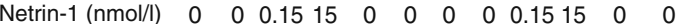

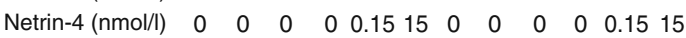

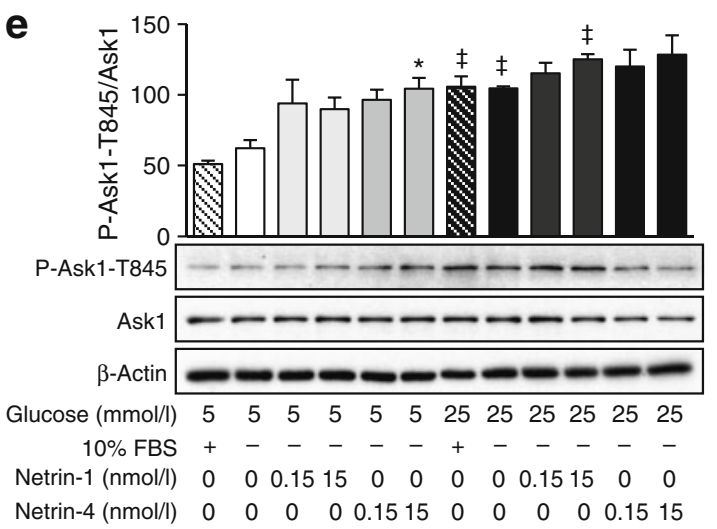

Fig. 8 Netrins can activate Akt and ERK pro-survival signalling in MIN6 cells. The phosphorylation level of Akt-Ser473 (a), Akt-Thr308 (b), ERK1/2-Thr202/Tyr204 (c), JNK1-Thr183 (d) and ASK1-Thr845 (e) were detected by Western blotting in MIN6 cells treated for 5 min with netrin-1 or netrin-4 ( $n=7-12) .{ }^{*} p<0.05$ compared with $5 \mathrm{mmol} / \mathrm{l}$ glucose serum-free control; ${ }^{\dagger} p<0.05$ compared with $25 \mathrm{mmol} / \mathrm{l}$ glucose serumfree control; ${ }^{\star} p<0.05$ compared with $5 \mathrm{mmol} / \mathrm{l}$ glucose of the same treatment
Hyperglycaemia-induced apoptosis is a complication of diabetes and probably plays a harmful role in islet transplantation. In the present study, we demonstrated that netrins significantly reduced caspase- 3 activity in high glucose. This is consistent with the pro-survival effects of netrins in other cell types, including neuronal, gastrointestinal epithelial and mammary cells $[25,27,36,47,48]$. The glucose-dependence of caspase- 3 activation mirrors the effects of blocking Notch signalling in adult islets [20].
Our investigation of the mechanisms involved in beta cell netrin signalling implicated neogenin and UNC5A. These receptors induce apoptosis in the absence of netrin and inhibit apoptosis when ligands are bound [40, 41]. Ligandbound netrin receptors sequester caspase-3, preventing its activation [26]. The proteasome-ubiquitin system has been implicated in DCC downregulation by netrin-1 in embryonic neurons [42]; indeed, our results are consistent with degradation controlling beta cell netrin receptor levels. The 
proliferative effect of netrin-1 in vascular smooth muscle cells during angiogenesis is mediated through neogenin [39]. Perhaps the lack of proliferative response to netrin-1 treatment was due to the decrease in neogenin upon treatment with netrin-1.

Nerve growth cone guidance by netrin-1 is dependent on cytoplasmic $\mathrm{Ca}^{2+}$ influxes via plasma membrane channels and ryanodine receptors [49]. In our hands, exposure of islet cells to netrin-1 did not acutely induce intracellular $\mathrm{Ca}^{2+}$ signals. Whether netrin-1 signalling in neurons requires cAMP is controversial [43]. Under our experimental conditions, netrin-1-treated MIN6 cells did not generate robust cAMP responses. The cAMP fluctuations observed in some beta cells following longer exposure times to netrin-1 could have been caused by other paracrine factors in this static milieu.

In summary, we determined that a large number of paracrine signalling loops are present in adult human and rodent islets. Examination of these genes is likely to reveal that many more factors influence islet survival and growth, both positively and negatively. We focused on the detailed mechanisms and function of netrins, which had not been previously described in normal adult islets. We demonstrated that netrins regulate caspase- 3 activation in a glucosedependent manner, via a mechanism involving their dependence receptors, neogenin and UNC5A, as well as upregulation of Akt and ERK pro-survival signalling. Our results lay the ground-work to allow exploitation of local autocrine and/or paracrine survival signalling for therapeutic purposes.

Acknowledgements We thank R. Tsien for the AKAR2 cAMP FRET sensor and G. Warnock (Centre for Human Islet Transplantation and Beta-cell Regeneration) for access to human islets and pancreas. We also thank B. Hu, T. Kalynyak, T. Albrecht and C. Der for technical assistance, and E. U. Alejandro, D. S. Luciani and K. Y. Chu for helpful advice and discussions. The research was supported by grants from the Juvenile Diabetes Research Foundation (JDRF) and the Stem Cell Network. J. D. Johnson was also supported by salary awards from JDRF, the Michael Smith Foundation for Health Research, the Canadian Institutes for Health Research and the Canadian Diabetes Association. Y. H. C. Yang. received scholarships from the Natural Sciences and Engineering Research Council and the University of British Columbia Four Year Fellowship.

Duality of interest The authors declare that there is no duality of interest associated with this manuscript.

\section{References}

1. Chiang MK, Melton DA (2003) Single-cell transcript analysis of pancreas development. Dev Cell 4:383-393

2. Yada T, Sakurada M, Ishihara H et al (1997) Pituitary adenylate cyclase-activating polypeptide (PACAP) is an islet substance serving as an intra-islet amplifier of glucose-induced insulin secretion in rats. J Physiol 505:319-328
3. Tsuda H, Iwase T, Matsumoto K et al (1992) Immunohistochemical localization of hepatocyte growth factor protein in pancreas islet A-cells of man and rats. Jpn J Cancer Res 83:1262-1266

4. Johnson JD, Bernal-Mizrachi E, Alejandro EU et al (2006) Insulin protects islets from apoptosis via Pdx1 and specific changes in the human islet proteome. Proc Natl Acad Sci USA 103:19575-19580

5. Beith JL, Alejandro EU, Johnson JD (2008) Insulin stimulates primary beta-cell proliferation via Raf-1 kinase. Endocrinology 149:2251-2260

6. Okada T, Liew CW, Hu J et al (2007) Insulin receptors in betacells are critical for islet compensatory growth response to insulin resistance. Proc Natl Acad Sci USA 104:8977-8982

7. Wideman RD, Yu IL, Webber TD et al (2006) Improving function and survival of pancreatic islets by endogenous production of glucagonlike peptide 1 (GLP-1). Proc Natl Acad Sci USA 103:13468-13473

8. Fujita Y, Wideman RD, Asadi A et al (2010) Glucose-dependent insulinotropic polypeptide is expressed in pancreatic islet alpha-cells and promotes insulin secretion. Gastroenterology 138:1966-1975

9. Widenmaier SB, Kim SJ, Yang GK et al (2010) A GIP receptor agonist exhibits beta-cell anti-apoptotic actions in rat models of diabetes resulting in improved beta-cell function and glycemic control. PLoS One 5:e9590

10. Fujinaka Y, Takane K, Yamashita H, Vasavada RC (2007) Lactogens promote beta cell survival through JAK2/STAT5 activation and BclXL upregulation. J Biol Chem 282:30707-30717

11. Sekine N, Wollheim CB, Fujita T (1998) GH signalling in pancreatic beta-cells. Endocr J 45(Suppl):S33-S40

12. Vasavada RC, Gonzalez-Pertusa JA, Fujinaka Y, Fiaschi-Taesch N, Cozar-Castellano I, Garcia-Ocana A (2006) Growth factors and beta cell replication. Int J Biochem Cell Biol 38:931-950

13. Beattie GM, Rubin JS, Mally MI, Otonkoski T, Hayek A (1996) Regulation of proliferation and differentiation of human fetal pancreatic islet cells by extracellular matrix, hepatocyte growth factor, and cell-cell contact. Diabetes 45:1223-1228

14. Cebrian A, Garcia-Ocana A, Takane KK, Sipula D, Stewart AF, Vasavada RC (2002) Overexpression of parathyroid hormonerelated protein inhibits pancreatic beta-cell death in vivo and in vitro. Diabetes 51:3003-3013

15. Yamamoto K, Miyagawa J, Waguri M et al (2000) Recombinant human betacellulin promotes the neogenesis of beta-cells and ameliorates glucose intolerance in mice with diabetes induced by selective alloxan perfusion. Diabetes 49:2021-2027

16. Szabat M, Johnson JD, Piret JM (2010) Reciprocal modulation of adult beta cell maturity by activin A and follistatin. Diabetologia 53:1680-1689

17. Goulley J, Dahl U, Baeza N, Mishina Y, Edlund H (2007) BMP4BMPR1A signaling in beta cells is required for and augments glucose-stimulated insulin secretion. Cell Metab 5:207-219

18. Yamamoto K, Hashimoto H, Tomimoto $\mathrm{S}$ et al (2003) Overexpression of PACAP in transgenic mouse pancreatic beta-cells enhances insulin secretion and ameliorates streptozotocin-induced diabetes. Diabetes 52:1155-1162

19. Rosenbaum T, Vidaltamayo R, Sanchez-Soto MC, Zentella A, Hiriart M (1998) Pancreatic beta cells synthesize and secrete nerve growth factor. Proc Natl Acad Sci USA 95:7784-7788

20. Dror V, Nguyen V, Walia P, Kalynyak TB, Hill JA, Johnson JD (2007) Notch signalling suppresses apoptosis in adult human and mouse pancreatic islet cells. Diabetologia 50:2504-2515

21. Cirulli V, Yebra M (2007) Netrins: beyond the brain. Nat Rev Mol Cell Biol 8:296-306

22. Chilton JK (2006) Molecular mechanisms of axon guidance. Dev Biol 292:13-24

23. De Breuck S, Lardon J, Rooman I, Bouwens L (2003) Netrin-1 expression in fetal and regenerating rat pancreas and its effect on the migration of human pancreatic duct and porcine islet precursor cells. Diabetologia 46:926-933 
24. Yebra M, Montgomery AM, Diaferia GR et al (2003) Recognition of the neural chemoattractant netrin-1 by integrins alpha6beta4 and alpha3betal regulates epithelial cell adhesion and migration. Dev Cell 5:695-707

25. Tang X, Jang SW, Okada M et al (2008) Netrin-1 mediates neuronal survival through PIKE-L interaction with the dependence receptor UNC5B. Nat Cell Biol 10:698-706

26. Forcet C, Ye X, Granger L et al (2001) The dependence receptor DCC (deleted in colorectal cancer) defines an alternative mechanism for caspase activation. Proc Natl Acad Sci USA 98:3416-3421

27. Llambi F, Causeret F, Bloch-Gallego E, Mehlen P (2001) Netrin-1 acts as a survival factor via its receptors UNC5H and DCC. EMBO J 20:2715-2722

28. Wang W, Reeves WB, Ramesh G (2009) Netrin-1 increases proliferation and migration of renal proximal tubular epithelial cells via the UNC5B receptor. Am J Physiol Renal Physiol 296: F723-F729

29. Kutlu B, Burdick D, Baxter D et al (2009) Detailed transcriptome atlas of the pancreatic beta cell. BMC Med Genomics 2:3

30. Hoffman BG, Robertson G, Zavaglia B et al (2010) Locus cooccupancy, nucleosome positioning, and $\mathrm{H} 3 \mathrm{~K} 4 \mathrm{mel}$ regulate the functionality of FOXA2-, HNF4A-, and PDX1-bound loci in islets and liver. Genome Res 20:1037-1051

31. Morrissy AS, Morin RD, Delaney A et al (2009) Next-generation tag sequencing for cancer gene expression profiling. Genome Res 19:1825-1835

32. Szabat M, Luciani DS, Piret JM, Johnson JD (2009) Maturation of adult beta-cells revealed using a Pdx1/insulin dual-reporter lentivirus. Endocrinology 150:1627-1635

33. Hulbert EM, Smink LJ, Adlem EC et al (2007) T1DBase: integration and presentation of complex data for type 1 diabetes research. Nucleic Acids Res 35:D742-D746

34. Zhang J, Hupfeld CJ, Taylor SS, Olefsky JM, Tsien RY (2005) Insulin disrupts beta-adrenergic signalling to protein kinase A in adipocytes. Nature 437:569-573

35. Liu Y, Stein E, Oliver T et al (2004) Novel role for netrins in regulating epithelial behavior during lung branching morphogenesis. Curr Biol 14:897-905

36. Srinivasan K, Strickland P, Valdes A, Shin GC, Hinck L (2003) Netrin-1/neogenin interaction stabilizes multipotent progenitor cap cells during mammary gland morphogenesis. Dev Cell 4:371-382
37. Zhang C, Meng F, Wang $C$ et al (2004) Identification of a novel alternative splicing form of human netrin-4 and analyzing the expression patterns in adult rat brain. Brain Res Mol Brain Res 130:68-80

38. Lee HK, Seo IA, Seo E, Seo SY, Lee HJ, Park HT (2007) Netrin-1 induces proliferation of Schwann cells through Unc5b receptor. Biochem Biophys Res Commun 362:1057-1062

39. Park KW, Crouse D, Lee M et al (2004) The axonal attractant netrin-1 is an angiogenic factor. Proc Natl Acad Sci USA 101:16210-16215

40. Delloye-Bourgeois C, Fitamant J, Paradisi A et al (2009) Netrin-1 acts as a survival factor for aggressive neuroblastoma. J Exp Med 206:833-847

41. Matsunaga E, Tauszig-Delamasure S, Monnier PP et al (2004) RGM and its receptor neogenin regulate neuronal survival. Nat Cell Biol 6:749-755

42. Kim TH, Lee HK, Seo IA et al (2005) Netrin induces downregulation of its receptor, Deleted in Colorectal Cancer, through the ubiquitin-proteasome pathway in the embryonic cortical neuron. J Neurochem 95:1-8

43. Ming GL, Song HJ, Berninger B, Holt CE, Tessier-Lavigne M, Poo MM (1997) cAMP-dependent growth cone guidance by netrin-1. Neuron 19:1225-1235

44. Garcia-Ocana A, Vasavada RC, Cebrian A et al (2001) Transgenic overexpression of hepatocyte growth factor in the beta-cell markedly improves islet function and islet transplant outcomes in mice. Diabetes 50:2752-2762

45. Otonkoski T, Cirulli V, Beattie M et al (1996) A role for hepatocyte growth factor/scatter factor in fetal mesenchyme-induced pancreatic beta-cell growth. Endocrinology 137:3131-3139

46. Li C, Chen P, Vaughan J, Lee KF, Vale W (2007) Urocortin 3 regulates glucose-stimulated insulin secretion and energy homeostasis. Proc Natl Acad Sci USA 104:4206-4211

47. Mazelin L, Bernet A, Bonod-Bidaud C et al (2004) Netrin-1 controls colorectal tumorigenesis by regulating apoptosis. Nature 431:80-84

48. Furne C, Rama N, Corset V, Chedotal A, Mehlen P (2008) Netrin-1 is a survival factor during commissural neuron navigation. Proc Natl Acad Sci USA 105:14465-14470

49. Hong K, Nishiyama M, Henley J, Tessier-Lavigne M, Poo M (2000) Calcium signalling in the guidance of nerve growth by netrin-1. Nature 403:93-98 